\title{
The Relationship Between Emotional Intelligence and Academic Achievement Among Undergraduate Students at Madda Walabu University
}

\author{
Zenebe Demissie Tekle* \\ Madda Walabu University, College of Education and Behavioral Studies, \\ Department of Psychology, Bale Robe, Ethiopia \\ Ashebir Demeke Tekletsadik (PhD) \\ Madda Walabu University, College of Education and Behavioral Studies, \\ Department of Psychology, Bale Robe, Ethiopia \\ Issa Aliye Sado \\ Madda Walabu University, College of Education and Behavioral Studies, \\ Department of Psychology, Bale Robe, Ethiopia \\ Mulugeta Deribe Damota (Assistant Professor) \\ Madda Walabu University, College of Education and Behavioral Studies, \\ Department of Psychology, Bale Robe, Ethiopia
}

\begin{abstract}
The research is financed by Madda Walabu University
Abstract

Emotional Intelligence (EI) has been a popular topic of debate in the field of education in general and Psychology in particular. It is considered as a successful predictor of academic achievement. The purpose of this study is to examine the relationship between emotional intelligence and academic achievement among undergraduate students at Madda Walabu University. In order to assess the relationship between emotional intelligence and academic achievement cross sectional research design was employed. Assessing Emotions Scale developed by Schutte et al., (2009) was used to measure the magnitude of emotional intelligence among students. Students' academic achievement was measured by cumulative grade point average collected from the registrar of the University. The collected data was analyzed quantitatively by using frequency, percentage, mean scores, Pearson correlation, and t-test. In general, the result indicated positive significant relationship between emotional intelligence and academic achievement, low emotional intelligence among students and significant difference between male and female students on their emotional intelligence. To improve emotional intelligence of student's teaching emotional and social skills is very important at University
\end{abstract}

Keywords: Academic Achievement, Emotional Intelligence

DOI: $10.7176 / \mathrm{NMMC} / 85-02$

Publication date: November $30^{\text {th }} 2019$

\section{Introduction}

There are many possible definitions of emotional intelligence. Emotional intelligence is the capacity to reason about emotions, and of emotions to enhance thinking. It includes the abilities to accurately perceive emotions, to access and generate emotions so as to assist thought, to understand emotions and emotional knowledge, and to reflectively regulate emotions so as to promote emotional and intellectual growth (Mayer, Salovey \& Caruso, 2004). Emotional Intelligence (EI) is also the subset of social intelligence that involves the ability to monitor one's own and others feelings and emotions, to discriminate among them and to use this information to guide one's thinking and actions (Salovey and Mayer, 1990).

Academic achievement is the outcome of education-the extent to which a student, teacher, and institution have achieved their educational goals. Academic achievement refers to the extent to which learners acquire the knowledge, skills, and proficiencies that the instructor seeks to teach or assign (Salvia and Ysseldyke, 2000).

Academic achievement can be referred here as academic intelligence, by academic intelligence means a typically defined by conventional definition and tests comprising so-called general ability and related abilities (Baron, 2000). Student's ability to express his or her personality and to enjoy rich and complex social relations depends largely on his mastery of academic matters (Nabeel and Nazir, 2003).

The development of emotional intelligence is an intentional, active and engaging process. When emotional intelligence skills are the focus of learning, teachers, and students building human development behavior that is indirectly related to the positive outcome of academic achievement (Ogundokun \& Adeyemo, 2010). There have indeed been some studies that demonstrate the predictive effects of emotional intelligence on academic 
achievements (Baron, 2003; Marquez, Marten \& Braket, 2006; Adeyemo, 2007). In addition several studies indicated the significant relationship between emotional intelligence and academic achievement. Nelson et al. (2002), Singh et al. (2009) and Parker et al.(2004) studies concluded that emotional intelligence is correlated with academic achievement. Jaeger \& Eagan, 2007; Fallahzadeh, 2011; Fatima, Shah, \& Kiani, 2011; Nasir, 2012; Radfer et al., 2012 conducted studies on the association between emotional intelligence and academic achievement. They result indicated significant and positive relationship with emotional intelligence and academic achievement.

Some studies inconsistently found non-significant relationship between emotional intelligence and academic achievement. Studies (Johnson, 2008; Suliman, 2010) indicated no relationship between emotional social intelligence and learning abilities or between their relationships to academic success. Moreover, studies by Olatoye, Akintunde, and Yakasai (2010) and Gilani, Waheed, Saleem and Shaukat (2015) also have found a negative insignificant relationship between emotional intelligence and academic achievement.

People with higher emotional intelligence are likely to have better social support, and fewer problematic interactions with others; less likely to abuse drugs and alcohol; more satisfied with their social networks and appear to receive more social support; seemed to more successfully avoid interpersonal arguments and fights; better able to avoid drug problems, arguments, and interpersonal violence (Mayer, Salovey \& Caruso, 2008).

Though emotional intelligence has uncountable benefits for students during they stay at higher institution and after graduation, lack of well-organized research may hinder the understanding of university community about students' emotional intelligence level and its effect in their academic achievement. Thus, this study is intended to assess the Relationship between Emotional Intelligence and Academic Achievement among Undergraduate Students at Madda Walabu University.

\section{Research Questions}

The research was intended to answer the following research questions.

$\checkmark$ What is the status of students' emotional intelligence?

$\checkmark \quad$ Is there a statistically significant relationship between emotional intelligence and academic achievement?

$\checkmark \quad$ Is there any statistically significant gender difference in emotional intelligence?

\section{Methods and Materials}

Study area

This study was conducted in Oromia Regional State, Bale Zone, and Madda Walabu University, Ethiopia. Madda Walabu University is founded in 1999 E.C as public higher education .The University is located in a southeastern part of Ethiopia, and $430 \mathrm{~km}$ away from the capital city, Addis Ababa. The name Madda Walabu is given to the university based on the place which is $227 \mathrm{KM}$ away from the Zonal town Robe to the South-West.

\section{Research Design}

To investigate the relationship between emotional intelligence and academic achievement, cross sectional research design was employed.

\section{Participants}

The population of this study was the second year and above undergraduate regular students at Madda Walabu University in the year 2018/2019 academic calendar. first year students were excluded because of the absence of CGPA at the time of data collection. In 2018/2019 academic year, the university is teaching $59002^{\text {nd }}$ year and above class students in three (Robe Goba, and Shashemene) campuses. Stratified random sampling was used to select sample representative from the whole population. The sample size for this study was determined by using Yamane's (1967) formula. $n=\frac{\mathrm{N}}{1+\mathrm{N}(\mathrm{e}) 2}$; Where $\mathbf{N}$ is the size of the population and $\mathbf{n}$ is the size of the sample, $\mathbf{e}$ is the level of precision, 0.05 alpha level is the context of the present study. The computed sample size for this study was 375 .

\section{Measures}

In order to collect the pertinent data, the researchers used "The Assessing Emotions Scale" developed by Schutte. et al., (2009) which is Likert scale. The scale includes 33 questions and specifically as follows: Perception of Emotion (items 5, 9, 15, 18, 19, 22, 25, 29, 32, 33), Managing Own Emotions (items 2, 3, 10, 12, 14, 21, 23, 28, 31), Managing Others ${ }^{e c}$ Emotions (items 1, 4, 11, 13, 16, 24, 26, 30), and Utilization of Emotion (items 6, 7, 8, 17, 20,27). A high score on the instrument indicates a high degree of emotional intelligence, the variables under the study contribute high to emotional intelligence, and the negative impact of emotional intelligence is high. CGPA of students' were collected from the registrar coordinators of the colleges and the main Registrar Directorate office of the University. 


\section{Data Analysis}

The collected data were organized, tabulated and analyzed by using frequency, percentage, mean scores, correlation, and t-test.

\section{Results}

\section{Descriptive Statistics}

Here below the data were tabulated and analyzed as the following

Table 1: average scores of students' emotional intelligence and academic achievement

\begin{tabular}{|l|l|l|l|l|l|}
\hline Variables & $\mathrm{N}$ & Minimum & Maximum & Mean & Std. Dev \\
\hline Emotional & 375 & 82.00 & 163.00 & 127.29 & 14.29 \\
\hline CGPA & 375 & 1.84 & 3.99 & 3.04 & 0.53 \\
\hline
\end{tabular}

Table 1 show that the average scores of emotional intelligence in general and subscales specifically.

Based on the result total emotional intelligence (TOTAL EI) minimum score 82 and maximum 163 ( $M$ $=127.29 ; S D=14.29)$, and CGPA minimum score 1.84 and maximum $3.99(M=3.04 .29 ; S D=0.53)$.

Table 2. Status of students' Emotional Intelligence(EI)

\begin{tabular}{|l|l|c|}
\hline EI & Frequency & Percent \\
\hline High & 188 & 50.1 \\
\hline Low & 187 & 49.9 \\
\hline Total & 375 & 100 \\
\hline
\end{tabular}

As indicated in above Table 2, 188 (50.1\%) of students have low emotional intelligence and $187(49.9 \%)$ of students have high emotional intelligence.

Table 3: The relationship between emotional intelligence and academic achievement

\begin{tabular}{|l|l|l|l|}
\hline \multirow{2}{*}{ Pearson correlation } & $\mathrm{r}$ & Sig. (2-tailed) & $\mathrm{N}$ \\
\cline { 2 - 4 } & $.166^{* *}$ & 001 & 375 \\
\hline
\end{tabular}

**. Correlation is significant at the 0.01 level (2-tailed).

As indicated in Table 3 there is significant positive weak relationship between emotional intelligence and academic achievement (CGPA), $\mathrm{r}(373)=.17 ; \mathrm{p}<0.01$.

Table 4: gender difference in emotional intelligence (result of T-test)

\begin{tabular}{|c|l|l|r|r|r|r|c|}
\hline \multirow{3}{*}{ TOTALEISUM } & Sex & $\mathrm{N}$ & Mean & Std. Deviation & Std. Error Mean & T-test & Sig \\
\cline { 2 - 8 } & Male & 176 & 129.50 & 12.40 & .935 & 4.06 & .00 \\
& Female & 199 & 123.88 & 14.16 & 1.00 & & \\
\hline
\end{tabular}

As depicted in above Table 4, an independent-samples t- test comparing the mean scores of the male and female student's emotional intelligence.

The result found that there is significant difference between the means of the two groups ( $\mathrm{t}(373)=4.06, \mathrm{p}$ $<.05)$. The mean score of the male students $(M=129.5 ; S D=12.4)$ was significantly differ than female students $(M=123.88, S D=14.16)$. This indicates that male students have high emotional intelligence than female students.

\section{Discussion}

The main focus of the present study was to examine the relationship between emotional intelligence and academic achievement. The study conducted that emotional intelligence skills are significantly associated academic achievement. The results in this study are consistent with findings from Nelson et al. (2002), Singh et al. (2009) and Parker et al. (2004). These studies concluded that emotional intelligence is correlated with academic achievement. The following studies have also the same notion. Jaeger \& Eagan, 2007; Fallahzadeh, 2011; Fatima, Shah, \& Kiani, 2011; Nasir, 2012; Radfer et al., 2012 conducted studies on the association between emotional intelligence and academic achievement. They result indicated significant and positive relationship with emotional intelligence and academic achievement.

Inconsistent with this study, studies (Johnson, 2008; Suliman, 2010) indicated no relationship between emotional social intelligence and learning abilities or between their relationships to academic success. More over studies by Olatoye, Akintunde, and Yakasai (2010) and Gilani, Waheed, Saleem and Shaukat (2015) have found a negative insignificant relationship between emotional intelligence and academic achievement.

Analysis on gender wise represents that there is significant difference between male and female students on their emotional intelligence. This result is inconsistent with the extant literature in this field (Nayab and Abida, 2013), their result showed that there is insignificant difference between emotional intelligence of male and female students. Hopkins and Bilimoria (2008) in their study found that there was no significant relationship between emotional intelligence and academic achievement of male and female students at the University of Punjab.

In this study, the scores of emotional intelligence 82 to 127 indicated low emotional intelligence level while scores 128 to 163 indicates high emotional intelligence level. Results found that a total of $50.1 \%$ students have 
low emotional intelligence level while $49.9 \%$ have high emotional intelligence level. This finding are consistent with the work of Hafsa (2016), his study found that university students have low emotional intelligence, this low scores showing weakness in emotional intelligence.

\section{Conclusion}

Almost half of the students included in the study had low emotional intelligence. This likely affects students' better social support, interactions with others; behavior to use drugs; more satisfaction with their social networks.

There is positive significant relationship between emotional intelligence and academic achievement. The study revealed that higher emotional intelligence is significantly related to better academic success among students. Emotionally intelligent student would have a better academic achievement or through emotional intelligence there is a possibility of improvement of academic achievement.

The mean score of the male students was significantly differing than female students. The result indicates that male students have high emotional intelligence than female students.

\section{The way forward}

Soft skills workshop based activities should be used to improve emotional intelligence of students and helps to reduce stress and anger that will also cultivate the emotional development of university students in order to assist them to identify their own emotion and personality.

Teaching emotional and social skills is very important at University; it can affect academic achievement positively not only during the year they are taught but during the years that follow as well.

\section{References}

Adeyemo. D.A. (2007). Moderating influence of Emotional Intelligence on the Link between academic selfefficacy and achievement of university students. Psychology and Developing Societies, 19, 2,199-213.

Bar-On, R. (2000). Emotional and social intelligence: Insights from the Emotional Quotient Inventory (EQ-i). In R. Bar-On and J. D. A. Parker (Eds.), Handbook of emotional intelligence. San Francisco: Jossey-Bass.

Bar-on, R. (2003). How important is it to educate people to be emotionally and social intelligent and can it be done? Perspective in Education 21, 4, 3-13.

Fallahzadeh, H. A. (2011). The Relationship between Emotional Intelligence and Academic Achievement in medical science students in Iran. Social and Behavioral Sciences, 30, $1461-1466$.

Fatima, N., H Shah, S. M., \& Kiani, A. (2011). An Empirical Evidence of Relationship between Emotional Intelligence (EI) and Academic Achievement (AA) of Undergraduate Students. International Journal of Education and Social Sciences (IJESS), 1(3).

Gilani, N., Waheed, S. A., Saleem, K., \& Shoukat, L. (2015). Do Emotions Affect Academic Achievement in Adulthood? Relationship between Postgraduate Students' Trait Emotional Intelligence and Achievement. The AYER, 2, 37-44.

Hafsa A.(2016).Emotional intelligence among Universities. Research Journal of Educational Studies and Review , 2(1)

Hopkins MM, Bilimoria D, 2008. Social and emotional competencies predicting success for male and female executives. J. Manag. Develop. 27 (1):13-35.

Jaeger, A. J., \& Eagan Jr, M. K. (2007). Exploring the value of emotional intelligence: A means to improve academic performance. Journal of Student Affairs Research and Practice, 44(3), 910-935.

Johnson, G. D. K. (2008). Learning styles and emotional intelligence of the adult learner. Unpublished doctoral dissertation, Auburn University, Alabama, USA.

Retrieved November 9, 2009, from http://etd.auburn.edu/etd/handle/10415/1066?show=full

Maruez, P.G., Martin, R.P, and Backet, M.A. (2006). Relating Emotional Intelligence to Social Competence and academic achievement in high school students. Psychotria,18 (Suppl) 18-23.

Mayer, J. D., Salovey, P., \& Caruso, D. R. (2004). Emotional intelligence: Theory, findings, and implications. Psychological Inquiry, 60, 197-215.

Mayer, J. D., Salovey, P., \& Caruso, D. R. (2008a). Emotional intelligence: New ability or eclectic traits? American Psychologist, 63, 503-517.

Nabeel T. and Nazir M., (2003). The relationship between Intelligence and Academic Achievement, Pak. J.Edu., $\mathrm{XX}(\mathrm{I})$.

Nasir, M. (2012). Emotional intelligence as a mediator in the relationship of cultural adjustment and academic achievement of international students. Academic Research International, 3(3), 275.

Nayab J.,Abdisa N.(2013). The Role of Emotional Intelligence in Academic Performance of Male and Female Students in the University of Punjab. Journal of Education and Practice 5(4)

Nelson, D.B., Jin, Y., Wang, X.H.(2002) Reliability and validity parameters for the Chinese version of the emotional skills assessment process. Unpublished manuscript, East china Normal University. Shanghai, 
China.

Ogundokun, M.O \& Adeyemo, A.D. (2010). Emotional Intelligence and Academic Achievement: The Moderating Influence of Age, Intrinsic and Extrinsic Motivation. The African Symposium: An Online Journal of the African Education Research Network; Volume 10, 2.

Olatoye, R. A., Akintunde, S., \& Yakasai, M. (2010). Emotional intelligence, creativity and academic achievement of business administration students. Electronic Journal of Research in Educational Psychology, $8(2), 763-786$.

Oyewunmi , Gilani, N., Waheed, S. A., Saleem, K., \& Shoukat, L. (2015). Do Emotions Affect Academic Achievement in Adulthood? Relationship between Postgraduate Students' Trait Emotional Intelligence and Achievement. The AYER, 2, 37-44.

Parker, J. D. A., Summerfeldt, L. J., Hogan, M. J., \& Majeski, S. (2004). Emotional intelligence and academic success: Examining the transition from high school to university. Personality and Individual Differences, 36, 163-172.

Radfar, S., Aghaie, M., Arani, M., Nooh, S., \& Saburi, A. (2013). Evaluation of Emotional Intelligence and Its Relation to the Academic Achievement in Medical Students. Tehran Students' Research Centers Network (Thrita), 2(1), 114-119.

Schutte, N.S., Malouff, J.M., \& Bhullar, N. (2009). The Assessing Emotions Scale. C. Stough, D. Saklofske \& J. Parker (Eds.), The Assessment of Emotional Intelligence. New York: Springer Publishing, 119-135. Song, L., Huang, G., Peng,

Salovey P. and Mayer J.D., (1990). Emotional Intelligence, Imagination, Cognition, and Personality, 9, $195-211$.

Salvia J. and Ysseldyke J. E., (2000). Assessment (8th ed.), New York: Houghton Mifflin.

Singh, B., Singh, M., \& Singh, K. (2009). The influence of emotional intelligence and learning style on student's academic achievement. Retrieved November 9, 2009,

Suliman,V.,(2010). The Relationship between Learning Styles, Emotional Social Intelligence, and Academic Success of Undergraduate Nursing Students. Journal of Nursing Research,18(2),136- 143.

Yamane, Taro. (1967). Statistics: An Introductory Analysis, 2nd ED., New York: Harper and Row. 